\title{
Studi Deskriptif Penyebab Kejadian Ketuban Pecah Dini (KPD) pada Ibu Bersalin
}

\author{
Budi Rahayu, Ayu Novita Sari \\ Prodi DIII Kebidanan, Stikes Ahmad Yani Yogyakarta \\ Jalan RingRoad Barat, Ambarketawang, Gamping, Ambarketawang, Sleman, Kabupaten Sleman, \\ Daerah Istimewa Yogyakarta 55294, Indonesia \\ Email: budiayu_88@yahoo.co.id
}

\begin{abstract}
Abstrak
Ketuban Pecah Dini merupakan pecahnya selaput ketuban sebelum waktunya. Penyebab KPD belum diketahui secara pasti, akan tetapi ada hubungannya dengan hipermotilitas rahim, selaput ketuban tipis, infeksi, multipara, usia ibu, letak janin, dan riwayat ketuban pecah dini sebelumnya. Dampak terjadinya KPD dapat menyebabkan infeksi maternal maupun neonatal, hipoksia atau kompresi tali pusat, sindrom deformitas janin, meningkatnya kelahiran dengan seksio sesarea atau gagalnya persalinan normal, dan meningkatnya morbiditas dan mortalitas maternal dan perinatal. Tujuan penelitian untuk mengetahui gambaran penyebab kejadian ketuban pecah dini pada ibu bersalin di RSUD Yogyakarta. Data yang didapat di Rumah Sakit Jogja yang mengalami Ketuban Pecah Dini selama Tahun 2016 adalah sebanyak 427 kasus. Penelitian ini menggunakan rancangan deskriptif kuantitafif dengan pendekatan waktu retrospektif. Populasi dalam penelitian ini yaitu semua ibu bersalin yang mengalami ketuban pecah dini di RSUD Yogyakarta tahun 2016 yang didapat dari rekam medik. Teknik pengambilan sampel yaitu dengan total sampling dengan jumlah 427 responden. Analisis data yang digunakan yaitu analisis univariat. Hasil penelitian sebagian besar responden adalah multipara sebanyak 245 orang (57,4\%), berusia 20-35 tahun sebanyak 265 orang (62,1\%), umur kehamilan $\geq 37$ minggu sebanyak 343 orang (80,3\%), pembesaran uterus normal sebanyak 410 orang (96,1\%), letak janin preskep sebanyak 396 orang (92,7\%). Kesimpulan gambaran penyebab kejadian ketuban pecah dini pada ibu bersalin meliputi multipara, usia 20-35 tahun, umur kehamilan $\geq 37$ minggu, pembesaran uterus normal, dan letak janin presentasi kepala.
\end{abstract}

Kata Kunci: ketuban pecah dini (KPD), ibu bersalin

\section{Descriptive Study of Premature Rupture of Membranes (PROM) in Maternity}

\begin{abstract}
Premature Rupture Membranes is a rupture of the membranes prematurely. KPD Cause not known with certainty, but nothing to do with uterine hypermotility, thin membranes, infections, multiparous, maternal age, location of the fetus, and previous history of premature rupture of membranes. Impact of the KPD can cause maternal or neonatal infection, hypoxia or compression of the umbilical cord, fetal deformity syndrome, increased Caesarean labour or normal delivery failure, and increased morbidity and maternal perinatal mortality. This study was to identify the cause of the incident picture premature rupture in women giving birth in hospitals in Yogyakarta. This study uses descriptive design kuantitatif used retrospective time approach. The population in this study are all mothers who have premature rupture of membranes in hospitals in Yogyakarta in obtained from medical records. Premature rupture of membrane in Yogyakarta Hospital there are 427 cases. A sampling technique that with a total sampling with 427 respondents. Analysis of the data used univariate analysis. The results that most respondents are multipara many as 245 people (57.4\%), aged 20-35 years as many as 265 people (62.1\%), gestational age $\geq 37$ weeks as many as 343 people (80.3\%), over distensi uteri as many as 410 people (96.1\%), where the fetus head presentation many as 396 people (92.7). In conclusion, overview of the causes of premature rupture events on maternal
\end{abstract}


includes multipara, 20-35 years of age, gestational age $\geq 37$ weeks, normal uterine enlargement, and the location of the fetus normal presentation.

Keywords: premature rupture of membranes (PROM), birth mothers

Info Artikel:

Artikel dikirim pada 12 April 2017

Artikel direvisi pada 18 September 2017

Artikel diterima pada 25 September 2017

DOI: http://dx.doi.org/10.21927/jnki.2017.5(2).134-138

\section{PENDAHULUAN}

Salah satu indikator untuk mengukur kualitas SDM adalah derajat kesehatan penduduk. Masalah kesehatan ibu, bayi, dan perinatal di Indonesia merupakan masalah nasional yang perlu mendapatkan prioritas utama untuk dicarikan pemecahannya, karena hal tersebut sangat erat kaitannya dengan kualitas sumber daya manusia (SDM) untuk generasi yang akan datang (1).

Angka kematian ibu (AKI) dan angka kematian bayi (AKB) merupakan salah satu indikator untuk mencerminkan derajat kesehatan ibu dan anak, selain sekaligus cerminan dari status kesehatan suatu negara. Hasil survey demografi dan kesehatan Indonesia (SDKI) tahun 2015, AKI yaitu 305 per 100.000 kelahiran hidup yang mengalami penurunan dari tahun 2012 yaitu 359 per 100.000 kelahiran hidup (2). Angka kematian bayi (AKB) sendiri menurut survei penduduk antar sensus (SUPAS) pada tahun 2015 yaitu 22 per 100.000 kelahiran hidup (3).

Berdasarkan Data Dinas Kesehatan Provinsi Yogyakarta pada tahun 2014 AKI di Provinsi Yogyakarta pada tahun 2014 yaitu 40 kasus kematian mengalami penurunan dibanding dengan tahun 2013 yaitu 46 kasus. Penyebab kematian ibu berdasarkan data Dinkes Provinsi Yogyakarta yaitu perdarahan, eklampsia/ preeklampsia dan infeksi. Kematian ibu yang disebabkan oleh infeksi yaitu sebanyak $11 \%$. Ketuban Pecah Dini merupakan salah satu penyebab infeksi (4).

Ketuban pecah dini (KPD) yaitu pecahnya selaput ketuban sebelum persalinan. Pada kehamilan aterm atau kehamilan lebih dari 37 minggu sebanyak 8-10\% ibu hamil akan mengalami KPD, dan pada kehamilan preterm atau kehamilan kurang dari 37 minggu sebanyak $1 \%$ ibu hamil akan mengalami KPD. KPD dapat menyebabkan infeksi yang dapat meningkatkan kematian ibu dan anak apabila periode laten terlalu lama dan ketuban sudah pecah. KPD pada ibu hamil primi jika pembukaan kurang dari 3 $\mathrm{cm}$ dan kurang dari $5 \mathrm{~cm}$ pada ibu hamil multipara. Penyebab KPD masih belum jelas akan tetapi KPD ada hubungannya dengan hipermotilitas rahim yang sudah lama, selaput ketuban tipis, infeksi, multipara, disproporsi, serviks inkompeten, dan lain-lain $(1,5)$.

Komplikasi ketuban pecah dini yang paling sering terjadi pada ibu bersalin yaitu infeksi dalam persalinan, infeksi masa nifas, partus lama, perdarahan post partum, meningkatkan kasus bedah caesar, dan meningkatkan morbiditas dan mortalitas maternal. Sedangkan komplikasi yang paling sering terjadi pada janin yaitu prematuritas, penurunan tali pusat, hipoksia dan asfiksia, sindrom deformitas janin, dan meningkatkan morbiditas dan mortalitas perinatal (6). Data yang didapat di Rumah Sakit Jogja yang mengalami Ketuban Pecah Dini selama Tahun 2016 adalah sebanyak 427 kasus. Tujuan penelitian adalah untuk mengetahui gambaran penyebab kejadian ketuban pecah dini pada ibu bersalin di RSUD Yogyakarta.

\section{BAHAN DAN METODE}

Penelitian ini menggunakan jenis metode penelitian deskriptif kuantitatif. Metode penelitian deskriptif yaitu penelitian yang hanya terfokus dengan menggambarkan atau menguraikan suatu keadaan didalam populasi tertentu, atau kata lain dari penelitian deskriptif yaitu penelitian penjelajahan (exploratory study). Analisis yang digunakan adalah analisis univariat. Jenis penelitian ini menggunakan pendekatan Retrospektif yaitu penelitian yang pendekatannya melihat kebelakang, dengan seperti itu pengumpulan data yang dilakukan dimulai dari akibat tertentu yang telah terjadi, data didapatkan dari rekam medis pasien atau data sekunder (7). Penelitian ini dilaksanakan di RSUD Yogyakarta. Banyaknya responden yang diambil dalam penelitian ini adalah 427 ibu yang melahirkan di Rumah Sakit Yogyakarta dengan mengalami ketuban pecah dini. 


\section{HASIL DAN BAHASAN}

\section{Hasil Analisis Univariat Studi Deskriptif Penyebab Kejadian Ketuban Pecah Dini (KPD) Pada Ibu Bersalin Di RSUD Yogyakarta}

Berikut merupakan data yang menggambarkan kejadian ketuban pecah dini di RSUD Yogyakarta tahun 2016.

Tabel 1. Gambaran Kejadian Ketuban Pecah Dini Di RSUD Yogyakarta

\begin{tabular}{|c|c|c|}
\hline Kategori & $f$ & $\%$ \\
\hline \multicolumn{3}{|l|}{ Paritas } \\
\hline Primipara & 159 & 37,2 \\
\hline Multipara & 245 & 57,4 \\
\hline Grande Multipara & 23 & 5,4 \\
\hline \multicolumn{3}{|l|}{ Usia Ibu } \\
\hline$<20$ tahun & 103 & 24,1 \\
\hline 20-35 tahun & 265 & 62,1 \\
\hline$>35$ tahun & 59 & 13,8 \\
\hline \multicolumn{3}{|l|}{ Umur Kehamilan } \\
\hline$<37$ minggu & 84 & 19,7 \\
\hline$\geq 37$ minggu & 343 & 80,3 \\
\hline \multicolumn{3}{|l|}{ Pembesaran uterus } \\
\hline Gemelli & 10 & 2,3 \\
\hline Polihidramnion & 7 & 1,6 \\
\hline Normal & 410 & 96,1 \\
\hline \multicolumn{3}{|l|}{ Letak Janin } \\
\hline Lintang & 7 & 1,6 \\
\hline Sungsang & 24 & 5,6 \\
\hline Preskep & 396 & 92,7 \\
\hline
\end{tabular}

Sumber: Data Sekunder Tahun 2015

Berdasarkan Tabel 1 diketahui bahwa kejadian KPD mayoritas pada ibu multipara sebanyak 245 $(57,4 \%)$ responden, dan pada usia 20-35 tahun sebanyak $265(62,1 \%)$ responden. Pada ibu bersalin mayoritas terjadi pada umur kehamilan $\geq 37$ minggu sebanyak $343(80,3 \%)$ responden, pembesaran uterus normal sebanyak $410(96,1 \%)$ responden, dan letak janin preskep sebanyak 396 (92,7\%) responden.

\section{Jumlah Paritas}

Wanita yang telah melahirkan beberapa kali maka akan lebih berisiko tinggi mengalami KPD pada kehamilan berikutnya. Menurut Sumadi dan Ariyani KPD banyak terjadi pada multipara (8). Hal ini didukung oleh hasil penelitian Sudarto dan Tunut, yang dilakukan di wilayah kerja Dinas Kesehatan kota Pontianak yaitu di Puskesmas Siantan Hilir yang dilaksanakan pada awal bulan Juli sampai Oktober 2015 menyatakan bahwa faktro yang memengaruhi kejadian KPD adalah paritas (9). Kehamilan yang terlalu sering dapat memengaruhi embriogenesis, selaput ketuban lebih tipis sehingga mudah pecah sebelum waktunya dan semakin banyak paritas semakin mudah terjadi infeksi amnion karena rusaknya struktur servik pada persalinan sebelumnya $(10,11)$.

Wanita dengan paritas kedua dan ketiga pada usia reproduktif biasanya relative memiliki keadaan yang lebih aman untuk hamil dan melahirkan, karena pada keadaan tersebut dinding uterus lebih kuat karena belum banyak mengalami perubahan, dan serviks belum terlalu sering mengalami pembukaan sehingga dapat menyanggah selaput ketuban dengan baik (10). Wanita yang telah melahirkan beberapa kali akan lebih berisiko mengalami KPD, karena jaringan ikat selaput ketuban mudah rapuh yang diakibatkan oleh vaskularisasi pada uterus mengalami gangguan yang mengakibatkan akhirnya selaput ketuban mengalami pecah spontan (12).

\section{Usia Ibu Melahirkan}

Usia ibu melahirkan yang memiliki resiko rendah adalah umur 20-35, $<20$ tahun dan $>35$ tahun memiliki resiko tinggi dalam proses persalinan. Akan tetapi untuk KPD sendiri secara patobiologi dari kehamilan dengan ketuban pecah dini masih belum banyak diketahui. Banyak faktor dan jalur yang dapat menyebabkan degradasi dari matriks selaput membran ekstrasellular antara lain: jumlah kolagen diselaput membran ekstrasellular, keseimbangan antara degradasi dan aktifitas perbaikan dari komponen matriks, enzim spesifik yang berfungsi sebagai pengendali dan pengatur aktifitas biofisik matriks membran ekstraseluler, infeksi terkait dengan keseimbangan enzim yang dihasilkan pada selaput membran ekstrasellular, aktivitas adanya peningkatan apoptosis pada daerah robekan selaput amnion (13).

\section{Umur Kehamilan}

Kehamilan aterm atau kehamilan $\geq 37$ minggu sebanyak 8-10\% ibu hamil akan mengalami KPD, dan sebanyak $1 \%$ kejadian KPD pada ibu hamil preterm $<37$ minggu $(1,14)$. Pada penelitian Susilowati dan Astuti bahwa sebagian besar ibu bersalin dengan KPD yaitu antara umur kehamilan 37-42 minggu (15). Saat mendekati persalinan terjadi peningkatan matrix metalloproteinase yang cenderung menyebabkan KPD dan pada trimester akhir akan menyebabkan selaput ketuban mudah pecah dikarenakan pembesaran 
uterus, kontraksi rahim, dan gerakan janin. Hal ini juga menunjukkan bahwa semakin tua umur kehamilan akan mengakibatkan pembukaan serviks dan peregangan selaput ketuban yang berpengaruh terhadap selaput ketuban sehingga semakin melemah dan mudah pecah $(1,11)$.

\section{Pembesaran Uterus}

Over distensi dapat menyebabkan terjadinya KPD karena distensi uterus atau over distensi yang membuat rahim lebih besar sehingga selaput ketuban lebih tipis dan mudah pecah (1). Hasil penelitian lain menyatakan bahwa faktor-faktor yang memengaruhi terjadinya KPD pada ibu hamil trimester III di RS Ban Lawang yaitu faktor over distensi sebanyak 4,83\% (16). Menurut Caughay bahwa over distensi yang disebabkan oleh polihidramnion dan kehamilan kembar mengakibatkan lebih tinggi resiko terjadi KPD (17). Wanita dengan kehamilan kembar beresiko tinggi mengalami KPD. Hal ini disebabkan oleh peningkatan massa plasenta dan produksi hormon yang dap memungkinkan ketegangan rahim meningkat sewaktu-waktu selaput ketuban dapat pecah secara tiba-tiba yang dapat diidentifikasi sebagai KPD (10).

\section{Kelainan Letak}

Kelainan letak pada janin dapat meningkatkan kejadian KPD karena kelainan letak dapat memungkinkan ketegangan otot rahim meningkat sehingga dapat menyebabkan KPD (18). Penelitian Suryaputri dan Anjarwati bahwa tidak ada hubunganya antara kelainan letak dengan kejadian KPD (17). Besar kecilnya janin dan posisi janin yang dikandung tidak menyebabkan peregangan pada selaput ketuban seperti pada keadaan normal, sungsang ataupun melintang, karena sebenarnya yang dapat mempengaruhi KPD adalah kuat lemahnya selaput ketuban dalam menahan janin $(1,17,18)$. Penelitian Suhaimi mengatakan bahwa KPD bisa disebabkan karena Peningkatan apoptosis pada selaput amnion berperan penting pada penipisan membran janin yang mengakibatkan terjadinya KPD. Peningkatan p53 akan meningkatkan munculnya kaspase-3 yang akan menyebabkan apoptosis yang berlebihan, sehingga dengan adanya peningkatan proses apoptosis ini dapat menyebabkan terjadinya KPD (19).

Penelitian lain mengatakan, bahwa ada hubungan letak susang dengan kejadian ketuban pecah dini, ini disebabkan karena pada letak sungsang dimana bokong menempati servik uteri dengan dengan keadaan ini pergerakan janin terjadi dibagian terendah karena keberadaan kaki janin yang menempati daerah servik uteri sedangkan kepala janin akan mendesak fundus uteri yang dapat menekan diafragma dan keadaan ini menyebabkan timbulnya rasa sesak pada ibu saat hamil (20).

\section{SIMPULAN DAN SARAN}

Gambaran penyebab kejadian ketuban pecah dini pada ibu bersalin meliputi multipara, usia 20-35 tahun, umur kehamilan $\geq 37$ minggu, pembesaran uterus normal, dan letak janin preskep.

Dengan mengetahui gambaran penyebab ketuban pecah dini tersebut diharapkan tenaga kesehatan dan suami, maupun keluarga yang terdekat dengan ibu bersalin lebih memperhatikan kondisi kesehatan ibu hamil.

\section{RUJUKAN}

1. Prawirohardjo S. IImu Kebidanan. Jakarta: PT Bina Pustaka Sarwono Prawirohardjo; 2010.

2. SDKI. Profil Kesehatan Indonesia Tahun 2015. Jakarta; 2015.

3. Badan Pusat Statistik. Penduduk Indonesia hasil SUPAS 2015 [Internet]. 2015 [cited 2017 Jun 9]. Available from: https://www.bps.go.id/index.php/ publikasi/1155

4. Dinkes DIY. Profil AKI di DIY. Yogyakarta; 2014.

5. Mochtar R. Sinopsis Obstetri. Jakarta: EGC; 2011.

6. Marni. Asuhan Kebidanan Patologi. Yogyakarta: Pustaka Pelajar; 2011.

7. Notoatmodjo S. Metodologi Penelitian Kesehatan. Jakarta: Rineka Cipta; 2012.

8. Sumadi N, Ariyani A. Faktor Risiko yang berhubungan dengan Kejadian Ketuban Pecah Dini. J IIm Kebidanan. 2013;1(1).

9. Sudarto, Tunut. Risiko Terjadinya Ketuban Pecah Dini Pada Ibu Hamil Dengan Infeksi Menular Seksual. J VOKASI Kesehat [Internet]. 2016;2(2):330-5. Available from: https://www. google.co.id/url? sa $=t \& r c t=j \& q=\& e s r c=s \&$ source $=$ web\&cd $=2 \& c a d=$ rja \&uact $=8 \&$ ved $=0$ ahU KEwjfp5ut87_WAhWDso8KHTNuBZMQFggqM AE\&url=http \%3A\%2F\%2 Fejournal.poltekkespontianak.ac.id\%2Findex.php\%2FJVK\%2Farticl e\%2Fdownload\%2F51\% 2F50\&usg=AFQjCNFv 1pmc57VjS9gT7FbkurBkkP2HIA 
10. Varney H. Buku Ajar Asuhan Kebidanan. 4th ed. Jakarta: EGC; 2008.

11. Manuaba. Buku Ajar Patologi Obstetri. Jakarta: EGC; 2008.

12. Cuningham F, Leveno K, Bloom S, Hauth J, Gilstrap IL, Wendstrom K. Chapter 21 Disorder of Aminic Fluid Volume. In: William Obstetrics. 22nd ed. USA: McGraw-Hill; 2006.

13. Menon R, Fortunato SJ. Infection and the role of inflammation in preterm premature rupture of the membranes. Best Pract Res Clin Obstet Gynaecol [Internet]. 2007 Jun;21(3):467-78. Available from: http://www.ncbi.nlm.nih.gov/pubmed/17448730

14. Medina TM, Hill DA. Preterm premature rupture of membranes: diagnosis and management. Am Fam Physician [Internet]. 2006 Feb 15;73(4):659_ 64. Available from: http://www.ncbi.nlm.nih.gov/ pubmed/16506709

15. Susilowati E. Gambaran Karakteristik Ibu Bersalin dengan Ketuban Pecah Dini di Rumah Sakit Panti Wilasa Citarum Semarang tahun 2009. J Kebidanan Panti Wilasa [Internet]. 2010;1(1). Available from: http://ejurnal.akbidpantiwilasa. ac.id/index.php/kebidanan/article/view/3

16. Suryaputri A, Anjarwati. Faktor-faktor yang Berhubungan dengan Kejadian Ketuban Pecah Dini pada Ibu Bersalin di RSUD Wates Kulon
Progo Tahun 2013. STIKES 'Aisyiyah Yogyakarta; 2013.

17. Caughey $A B$, Robinson JN, Norwitz ER. Contemporary diagnosis and management of preterm premature rupture of membranes. Rev Obstet Gynecol [Internet]. 2008;1(1):11-22. Available from: http://www.ncbi.nlm.nih.gov/ pubmed/18701929

18. Zainal A. Faktor-Faktor yang Mempengaruhi Kejadian Ketuban Pecah Dini pada Ibu Hamil Trimester III di Rumah Sakit Bantuan Lawang Poltekkes RS Dr. Soepraoen. J Hesti Wirasati [Internet]. 2016 [cited 2016 Jan 1];4(1). Available from: http://pasca.unhas.ac.id/jurnal/file/ abdbe934df5c895d7deebd756cc04c1.pdf

19. Suhaimi D. Protein P53 Sebagai Faktor Risiko Terjadinya Ketuban Pecah Dini. Indones J Appl Sci [Internet]. 2012 [cited 2017 Sep 19];2(2). Available from: http://jurnal.unpad.ac.id/ijas/ article/view/2738/2374

20. Waters TP, Mercer BM. The management of preterm premature rupture of the membranes near the limit of fetal viability. Am J Obstet Gynecol [Internet]. 2009 Sep;201(3):230-40. Available from: http://www.ncbi.nlm.nih.gov/ pubmed/19733274 